\title{
Роль рентгеноангіохірургічних методів у діагностиці та лікуванні паціентів із конотрункальними вадами серця та великими аорто- легеневими колатеральними артеріями
}

\author{
O. D. BABLIAK, A. V. MAKSYMENKO, O. O. MOTRECHKO \\ SI "Scientific and Practical Medical Center on Chil's Cardiology and Cardiosurgery of MPH of Ukraine", Kyiv
}

\section{THE ROLE OF ENDOVASCULAR METHODS IN DIAGNOSIS AND TREATMENT OF THE PATIENTS WITH CONOTRUNCUL HEART DEFECTS AND MAJOR AORTOPULMONARY COLLATERAL ARTERIES}

\begin{abstract}
У роботі описано та проаналізовано методи рентгенангіохірургічних процедур та операцій, які проводили 83 оперованим пацієнтам з конотрункальними вадами серця та великих аорто-легеневих колатеральних артерій (ВАЛКА) з 2007 до 2014 р. Всього було проведено 284 ангіопроцедури та 65 ангіооперацій. Катетеризація серця 3 рентгенангіографією залишається обов'язковим методом у діагностиці та плануванні лікування пацієнтів із конотрункальними уродженими вадами серця з ВАЛКА. Широкий спектр рентгенохірургічних операцій дозволяє оптимізувати гемодинаміку вади на різних етапах хірургічного лікування.

The X-ray surgical methods, which were used for diagnosis and treatment of the 83 patients with conotruncul heart defects and major aortopulmonary collateral arteries (MAPCA) from 2007 to 2014 are analyzed in the article. A total number of procedures was 284 angioprocedures and 65 angiooperations. The heart catheterization with angiography remains the obligatory method in the management of patients with conotruncal heart defects and MAPCA. A wide range of X-ray surgical procedures helps to optimize the hemodynamic parameters before and after anatomic correction.
\end{abstract}

Постановка проблеми і аналіз останніх досліджень та публікацій. Наявність великих аортолегеневих колатеральних артерій (ВАЛКА) при конотрункальних уроджених вадах серця ускладнює хірургічне лікування, збільшує ризик операцій, погіршує загальний прогноз виживання пацієнтів [1-4]. Операція об'єднання легеневих гілок та ВАЛКА в одне легеневе русло має назву уніфокалізації (УФ) легеневих артерій. Операція анатомічної корекції вади з виправленням інтракардіальної патології має назву радикальної корекції (РК) вади. Крім хірургічних методів, у лікуванні пацієнтів велика роль відводиться рентгенохірургічним методам [2-4].

Мета роботи: проаналізувати методи рентгенохірургічних процедур та операцій, які проводили пацієнтам із конотрункальними вадами серця та ВАЛКА.

Матеріали і методи. 32007 до 2014 р. включно в ДУ “Науково-практичний медичний центр дитячої кардіології та кардіохірургії МОЗ України” було проліковано 83 пацієнти з конотрункальними вадами та великими аорто-легеневими колатеральними артеріями, яким проведено 284 ангіопроцедури та 65 ангіооперацій.
Зондування серця $з$ рентгеноангіографією було обов'язковим інструментальним методом обстеження для пацієнтів із конотрункальною вадою серця та ВАЛКА. Метод може бути використаний з діагностичною або лікувальною метою.

3 діагностичною метою катетеризацію серця з рентгеноангіографією проводили до початку хірургічного лікування та після кожної проведеної операції. Якщо хірургічне лікування здійснювали в декілька етапів, відповідно зростала кількість необхідних діагностичних процедур, які оцінювали ефективність вже проведеної хірургічної операції і готовність до наступної хірургічної операції.

Головним завданням було оцінити легеневе артеріальне русло від початкових сегментів до дистальних гілок - оцінювали і нативні гілки легеневої артерії, і ВАЛКА. Всім хворим обов'язково виконували: 1) праву і ліву вентрикулографію; 2) аортографію; 3) селективну ангіографію кожної ВАЛКА в двох проекціях; 4) ретроградну ангіографію легеневих артерій через легеневі вени (за відсутності візуалізації антеградним шляхом). Щодо нативних легеневих гілок, важливо було визначити наявність 
або відсутність центральних гілок легеневої артерії, ступінь їхньої гіпоплазії, з'єднаність між собою, наявність з'єднання з ВАЛКА. Під час рентгеноангіографії кожну ВАЛКА оцінювали в двох проекціях. До уваги брали такі показники: розміри ВАЛКА в зоні кореня легень, кількість сегментів, які кровопостачала дана ВАЛКА, місце відходження та особливості ходу ВАЛКА, віддаленість її від центральних легеневих гілок, наявність стенозів за ходом ВАЛКА, локалізація стенозів, наявність анастомозів із нативними гілками чи іншими ВАЛКА та значущість даних анастомозів, наявність легеневої гіпертензії в сегментах, які кровопостачаються ВАЛКА.

Із лікувальною метою рентгенохірургічні методики використовували за наявністю показань на всіх етапах лікування пацієнта - доопераційному, міжетапному та після проведення анатомічної корекції. Нижче перераховуємо варіанти процедур, які використовували у наших пацієнтів:

Балонна пластика/стентування ВАЛКА.

Балонна пластика/стентування уніфокалізованих центральних та периферичних легеневих гілок.

Балонна пластика правошлуночково-легеневого кондуїту.

Стентування відкритої артеріальної протоки.

Рентгенохірургічна балонна дилатація стенозу клапана легеневої артерії.

Рентгенохірургічна перфорація клапана легеневої артерії при АЛА.

Емболізація ВАЛКА.

Було проаналізовано рентгенохірургічні методи діагностики щодо можливості виявлення аномалій легеневого кровотоку при конотрункальних вадах 3 ВАЛКА. Оцінено ефективність методів з точки зору планування хірургічного лікування. Проаналізовано спектр та ефективність рентгенохірургічних операцій до та після початку хірургічного лікування.

Результати досліджень та їх обговорення. Із 2007 до 2014 р. 83 пацієнтам було проведено 284 діагностичні ангіопроцедури. У ході роботи ми розробили план опису ВАЛКА перед хірургією, який складається на підставі даних ангіографії та комп’ютерної томографії:

Порядковий номер ВАЛКА - нумерація йде за ходом аорти. Коронарні артерії, висхідна аорта, судини дуги аорти за порядком, дистальна дуга аорти і низхідна аорта.

Розміри ВАЛКА: описуються найбільший та найменший діаметри ВАЛКА, наявність дискретних чи дифузних стенозів.

Гіпертензивність ВАЛКА: визначали на підставі відсутності стенозів та прямих вимірів тиску в дистальних відділах ВАЛКА.
Кількість легеневих сегментів, які кровопостачає ВАЛКА.

Розміщення та проходження ВАЛКА: місце початку ВАЛКА, напрям відходження ВАЛКА, розміщення ВАЛКА відносно трахеї і головних бронхів та відносно стравоходу.

Комунікантність ВАЛКА: вираження з'єднання 3 іншими ВАЛКА або нативними легеневими артеріями.

Відповідно до напрацьованого досвіду лікування пацієнтів з конотрункальними вадами та ВАЛКА опис вищенаведених критеріїв $є$ необхідним для прийняття рішення про необхідність та доцільність перев'язки чи уніфокалізації кожної конкретної ВАЛКА. Дане рішення $\epsilon$ найважливішим у плануванні хірургічної оптимізації легеневого кровотоку, оскільки обсяг, терміни та зона УФ визначають доступ та методику УФ.

Наводимо узагальнені дані щодо анатомічнофункціональної характеристики ВАЛКА у наших пацієнтів. Всього нами було ідентифіковано 260 ВАЛКА на 83 пацієнти. Кількість ВАЛКА коливалася від 1 до 6 на пацієнта, в середньому - 3,1 1 на пацієнта, медіана - 3. Кількість ВАЛКА, які було

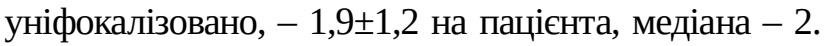
Інші ВАЛКА кваліфіковано як незначущі і залишено або перев'язано як комунікантні.

Двадцять сім пацієнтів мали гіпертензивні ВАЛ$\mathrm{KA}$, які кровопостачали не менше 50 \% сегментів легеневої тканини (рис. 1).

Наявність ВАЛКА призводить до порушення типового розгалуження легеневого артеріального дерева. Крім того, легеневе артеріальне русло, яке кровопостачається ВАЛКА, має ангіографічний вигляд, який відрізняється від норми. Легеневі артеріальні судини в зоніВАЛКАможутьбутидилатованими, покрученими, стенозованими дистально та ін. Дані аномалії прийнято називати порушенням “арборизації” (від лат. arbor - дерево). Оцінити функціонально, наскільки легеневі сегменти $є$ повноцінними за функцією порівняно 3 сегментами, які з'єднані 3 нативними легеневими артеріями, неможливо. Однак макроскопічно ангіографічна картина відрізняється від нормального легеневого русла. Крім того, порушення арборизації можуть бути як у зоні постачання гіпертензивними ВАЛКА, так і в зоні постачання негіпертензивними ВАЛКА (рис. 2).

Ми оцінили кількісно порушення арборизації в наших пацієнтів. Число хворих, у яких кількість легеневих сегментів із видимими порушеннями арборизації було менше половини, склало 35 \% (29 пацієнтів). 23 пацієнти мали порушення арборизації від 50 до 75 \% легеневих сегментів, а 31 хворий мав виражені порушення арборизації в 75-100 \% легеневих сегментів (рис. 3). 

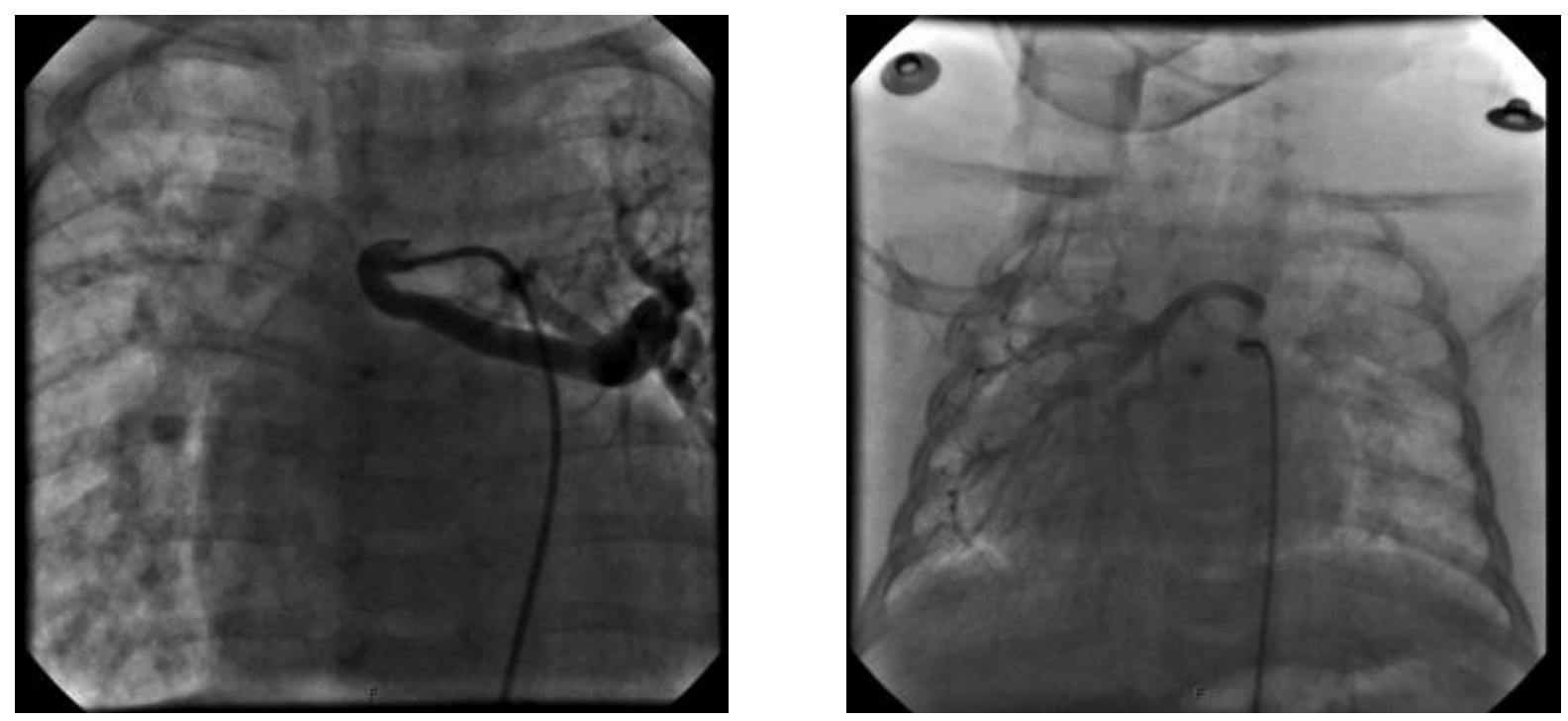

Рис. 1. Гіпертензивні ВАЛКА до верхньої частини лівої легені та до нижньої частки правої легені.
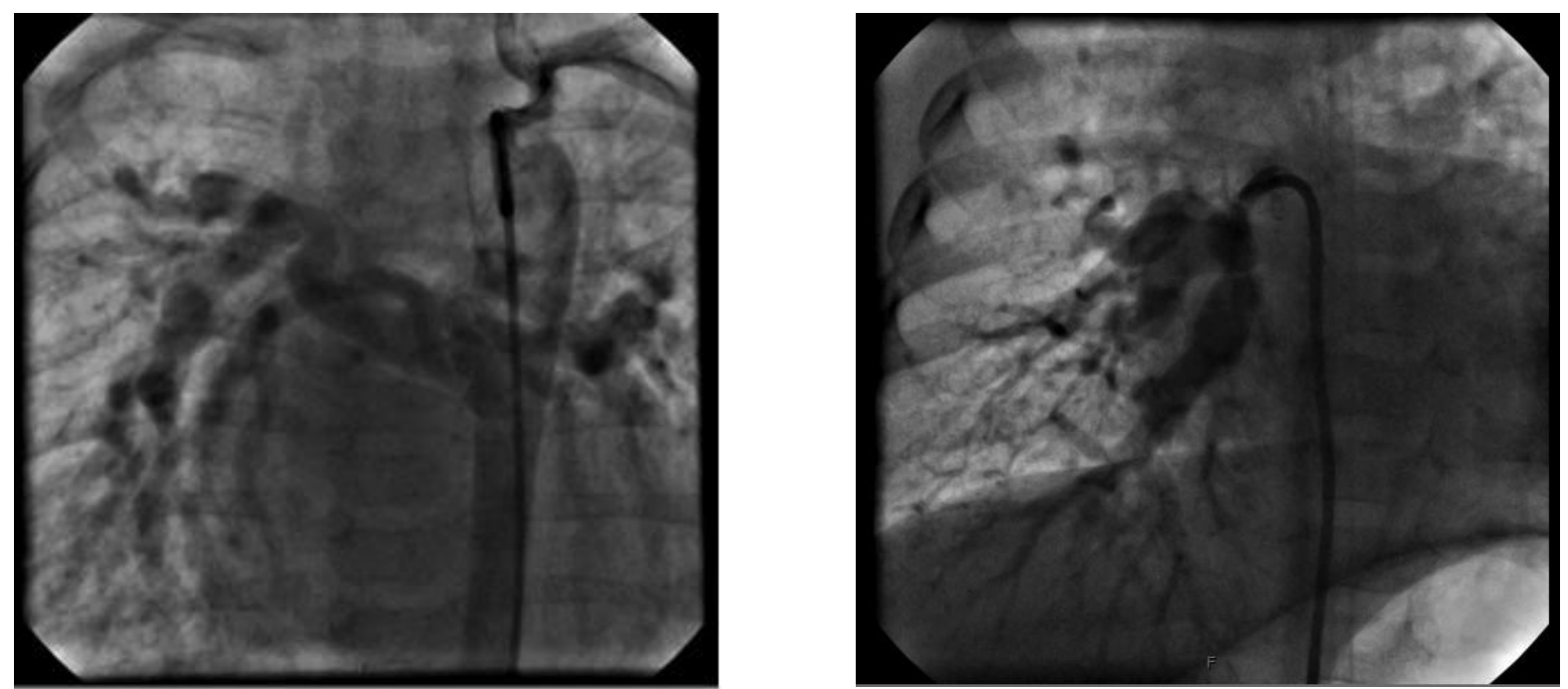

Рис. 2. Порушення “арборизації” легеневого дерева в зоні кровопостачання гіпертензивної(зліва) та негіпертензивної (справа) ВАЛКА.

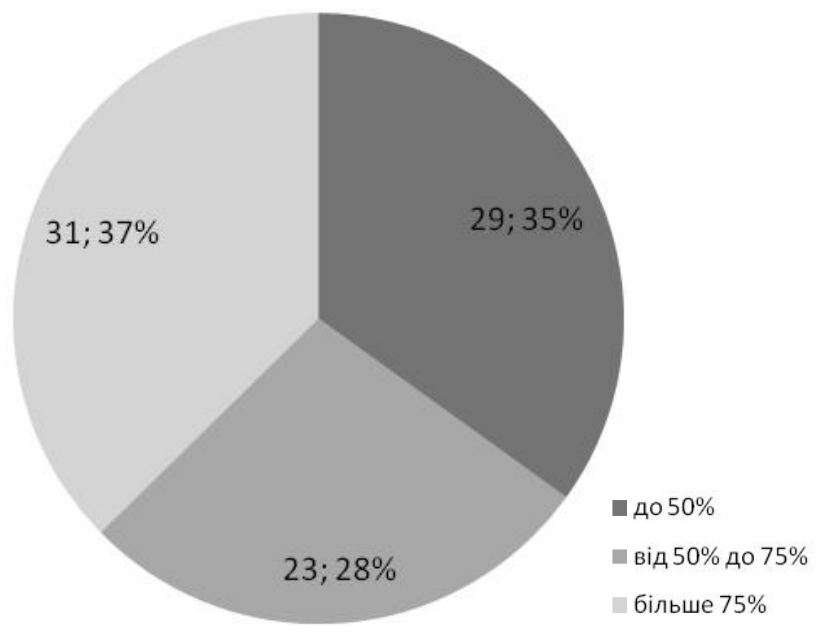

Рис. 3. Діаграма розподілу пацієнтів із порушенням арборизації за кількістю легеневих сегментів.
Центральні нативні легеневі артерії були гіпоплазованими у всіх випадках. Крім того, вони могли мати додаткові аномалії розвитку (рис. 4). Стовбур міг бути подовженим, гіпопластичним, біфуркація легеневого стовбура ротована. Подібні зміни ми виявили в 3 пацієнтів.

У ході роботи ми ідентифікували такі рідкісні аномалії: відходження ВАЛКА від коронарної артерії (1 пацієнт) (рис. 5); відходження ВАЛКА від висхідної аорти (1 пацієнт) (рис. 6).

Одним із факторів, який утруднює процедуру УФ в умовах серединної стернотомії, $є$ ретроезофагеальне проходження ВАЛКА, яка йде від низхідної аорти. Ми виявили ретроезофагеальну ВАЛКА в 19 наших пацієнтів. Запідозрити ретроезофагеальний хід ВАЛКА можна за даними ангіографії (рис. 7). Підтверджується така аномалія за даними комп’ютерної томографії (рис. 8). 


\section{З ДОСВІДУ РОБОТИ}
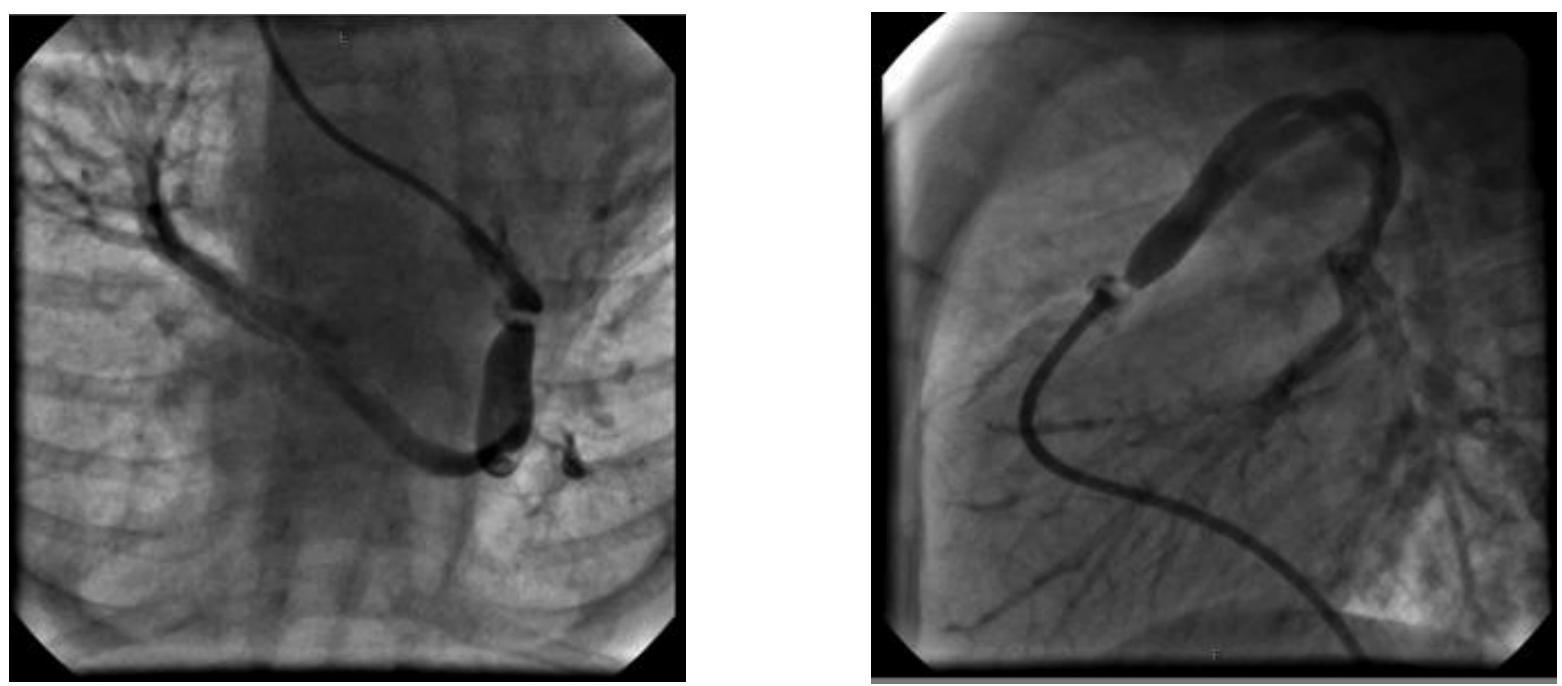

Рис. 4. Пряма та бокова проекції. Аномалія центральних нативних легеневих гілок.
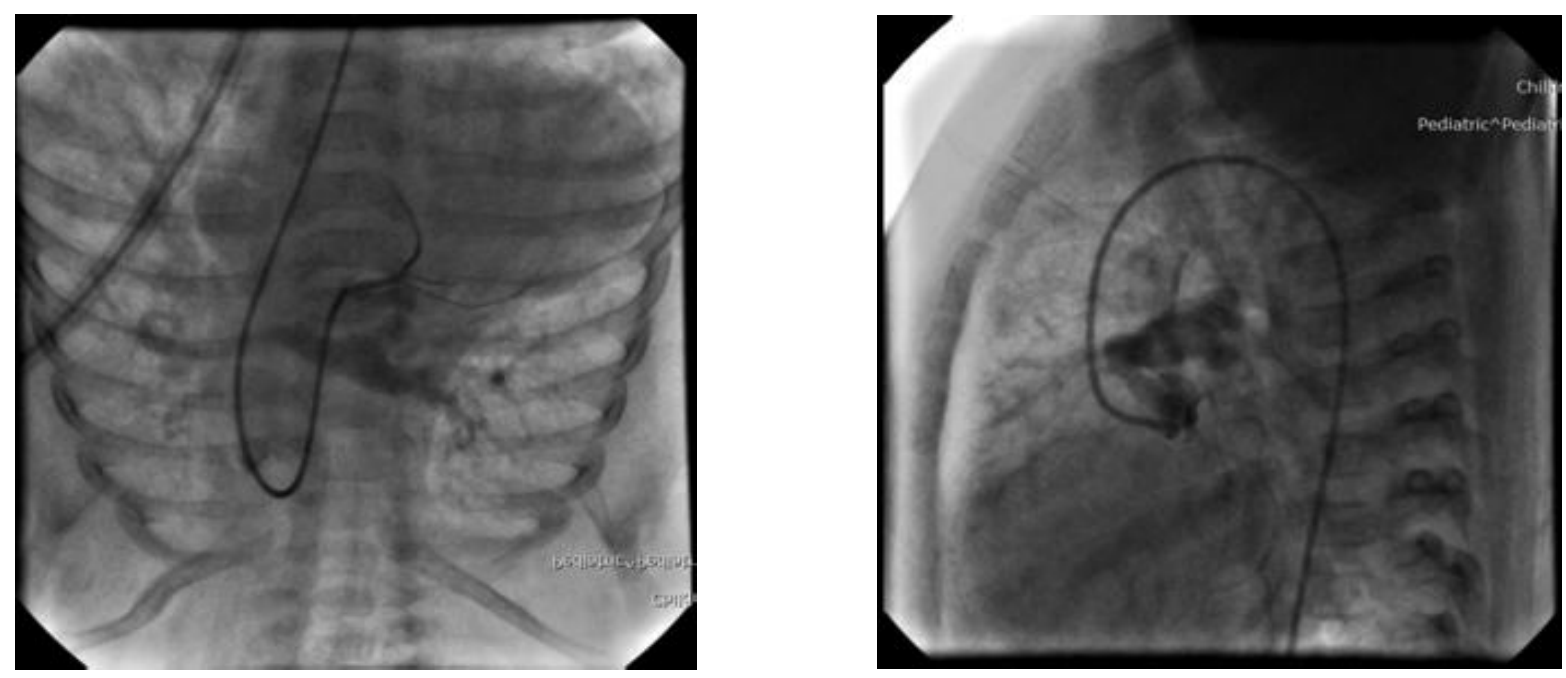

Рис. 5. ВАЛКА від лівої коронарної артерії до стовбура ЛА. Пряма та бокова проекції.

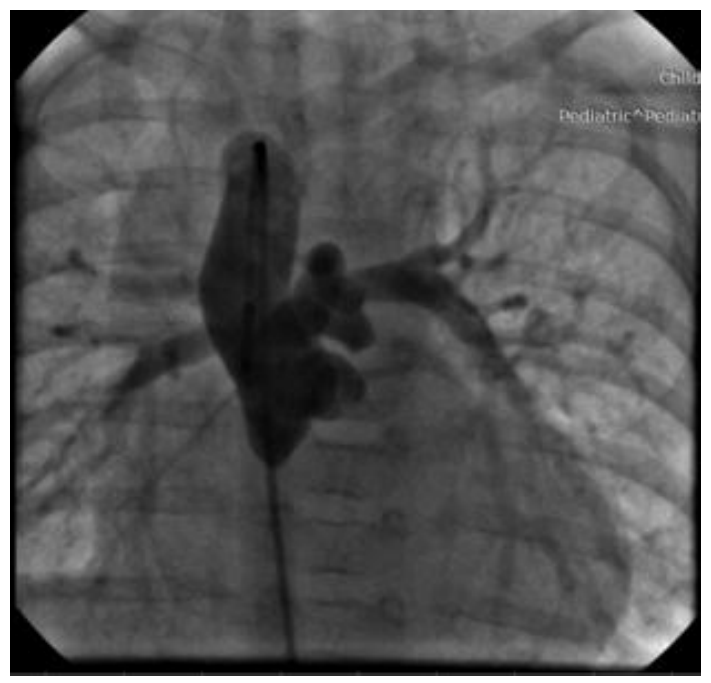

Рис. 6. ВАЛКА від висхідної аорти до ЛА.

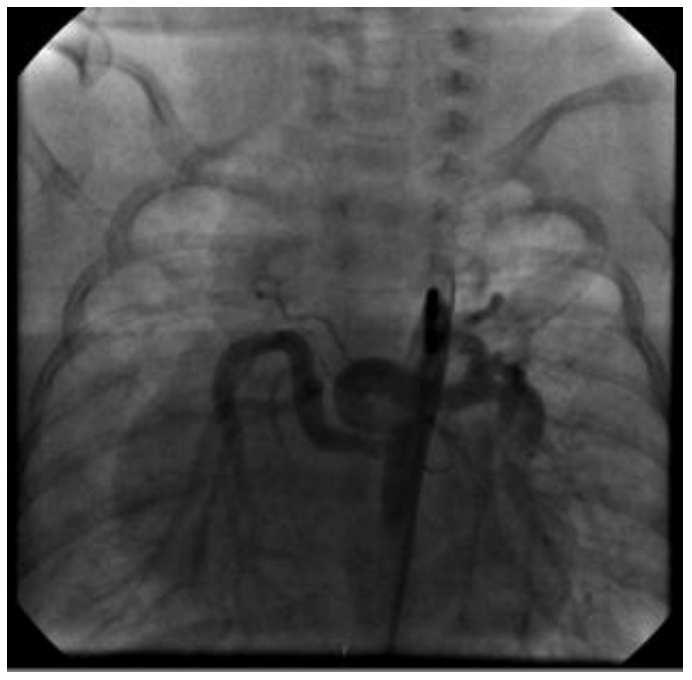

Рис. 7. Ретроезофагеальна ВАЛКА до правої легені при лівосторонній дузі аорти (ангіографія з низхідної аорти). 

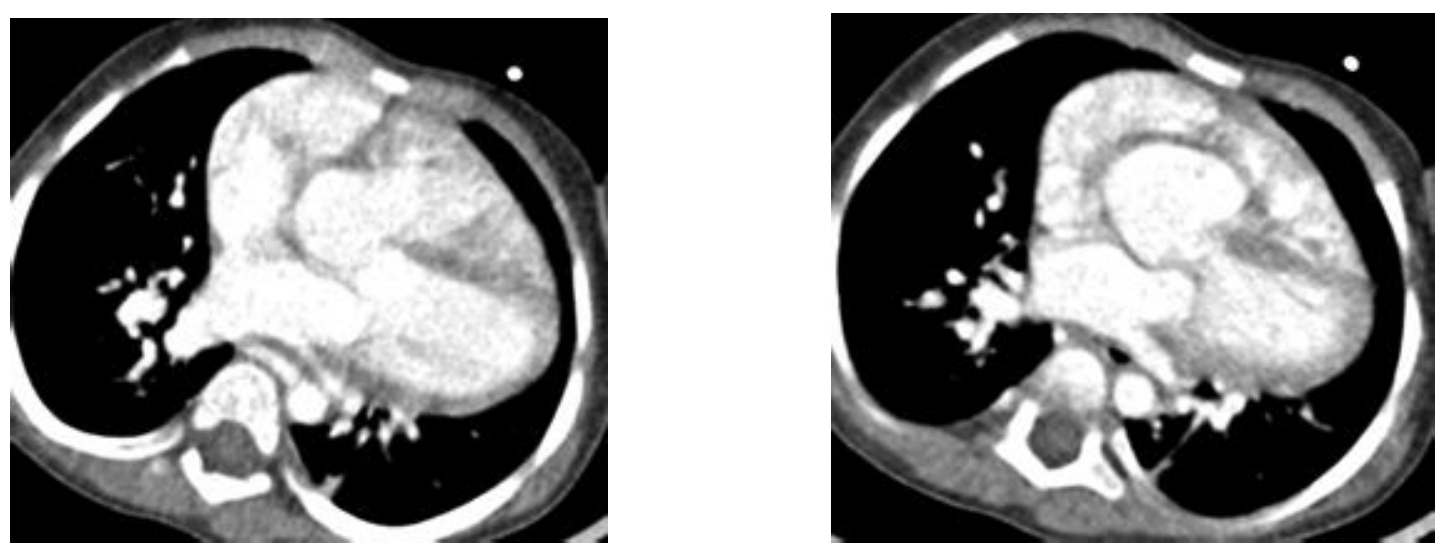

Рис. 8. Ретроезофагеальна ВАЛКА до правої легені при лівосторонній дузі аорти (комп’ютерна томографія).

Якщо в ході діагностичної процедури виявляли патологію, яку могли усунути ендоваскулярним методом, проводили ангіооперацію. Із 83 хво- рих ангіооперації було проведено в 39 пацієнтів, яким виконано 65 ангіооперацій. Наводимо перелік рентгенохірургічних операцій (табл. 1).

Таблиця 1. Перелік рентгенохірургічних операцій

\begin{tabular}{||c|c||}
\hline \multicolumn{1}{|c|}{ Показник } & Кількість \\
\hline До початку хірургічного лікування: & 11 \\
\hline - балонна дилатація/перфорація клапана ЛА & 1 \\
\hline - балонна атріосептостомія & 2 \\
\hline - стентування відкритої артеріальної протоки & 2 \\
\hline - стентування ВАЛКА & 30 \\
\hline Після хірургічних операцій: & 5 \\
\hline - балонна пластика гілок та уніфокалізованих ВАЛКА & 4 \\
\hline - стентування гілок та уніфокалізованих ВАЛКА & 8 \\
\hline - балонна дилатація зони системно-легеневого анастомозу & 2 \\
\hline - балонна дилатація кондуїту & 65 \\
\hline - емболізація ВАЛКА & \\
\hline Всього ангіооперацій & \\
\hline \hline
\end{tabular}

Всього з метою оптимізації легеневого кровотоку до початку хірургічного лікування проведено 16 ангіооперацій. Найчастішим втручаннням була балонна дилатація/перфорація клапана ЛА. Після хірургічних операцій проведено 49 ангіооперацій на різних етапах оптимізації легеневого кровотоку і після виконання РК. Найчастішим втручанням була балонна пластика уніфокалізованих гілок легеневої артерії та ВАЛКА.

Підсумовуючи вищенаведене, відзначимо, що було проведено 65 рентгенохірургічних операцій у 39 (47 \%) хворих з 83 пацієнтів. У 15 (18\%) пацієнтів виконано $\geq 2$ ангіооперацій. Рентгенохірургічні втручання мали різні завдання: оптимізацію легеневого кровотоку на доопераційному етапі, реабілітацію нативних легеневих артерій шляхом дилатації/перфорації клапана

\section{СПИСОК ЛІТЕРАТУРИ}

1. Baker E. J. Tetralogy of Fallot with Pulmonary Atresia // In: R. H. Anderson, E. J. Backer, eds. Pediatriccardiology, 3th ed. Philadelphia: ChurchillLivingstone. - 2010. - P. 774-793.

2. Aninstitutional approachto, and results for, patient with tetralogy with pulmonary atresiaandmajor systemic-to-pulmonary collateralarteries / W. M. DeCampli, R. Argueta-Morales, J. Zabinsky [et al.] // Cardiology in the Young. - 2010. - Vol. 20(Suppl. 3). - P. 128-134. легеневої артерії, усунення залишкової патології після хірургічної корекції, оптимізацію легеневого кровотоку після процедури УФ і після операції РК. Ангіооперації проводили в пацієнтів із різними хірургічними підходами, дещо частіше-у пацієнтів з одномоментною УФ та РК. У цілому, рентгенохірургічні методи лікування дозволили в групі складних пацієнтів покращити результати лікування, уникнути додаткових хірургічних втручань, оптимізувати гемодинаміку після РК.

Висновки. Рентгенохірургічні методи діагностики та операцій відіграють велику роль у лікуванні пацієнтів 3 конотрункальними уродженими вадами серця з ВАЛКА. Широкий спектр рентгенохірургічних операцій дозволяє оптимізувати гемодинаміку вади на різних етапах хірургічного лікування.

3. Lofland G. Anoverview of pulmonary atresia, ventricular septaldefect, andmultipleaortapulmonary collateral arteries / G. Lofland // Progress in Pediatric Cardiology. - 2009. - Vol. 26. - P. 65-70.

4. Malhotra S. P. Surgical management of pulmonary atresia with ventricular septal defectandmajoraor to pulmonary collaterals: a protocolbased approach S. P. Malhotra, F. L. Hanley // Semin Thorac. Cardiovasc. Surg. Pediatr. Card. Surg. Ann. - 2009. - Vol. 12. - P. 145-151.

Отримано 12.03.15 